\title{
Risâletü'n-Nushiyye'de İletişim Fiilleri
}

\section{Communication Verbs in Risâletü'n-Nushiyye}

\author{
Araş. Gör. Dr. Fatih DOĞRU(D)
}

\begin{abstract}
$\ddot{O} z$
Yunus Emre tarafindan mesnevi türünde yazılan Risâletü'n-Nushiyye, edebî değeri ve taşıdığı dil malzemesi yanında Anadolu sahasında manzum nasihatname geleneğinin öncüsü olması bakımından da önem arz etmektedir. Tasavvufi ve öğretici nitelikteki bu eserde fiil sınıflandırmalarında temel sınıflardan biri olarak yer verilen iletişim fiillerinin yer yer öne çıktığı görülmektedir. Birçok araştırmacı tarafından fiilleri; biçim bilgisel, söz dizimsel, anlamsal vd. özelliklerine göre sınıflandırma denemeleri yapılmıştır. $\mathrm{Bu}$ çalışmada fiillerin anlamsal özelliklerine göre sınıflandırma çalışmalarında yer verilen iletişim fiillerinin Yunus Emre'nin Risâletü'n-Nushiyye adlı eserindeki kullanılışı ele alınacaktır. İletişim fiillerini, fiilleri anlamsal özelliklerine göre ayırdığı 57 sınıftan biri olarak değerlendiren Levin'in (1993) çalışması çalışmada esas kabul edilecektir. Levin, iletişim fiillerini kendi içinde mesaj aktarma fiilleri (verbs of transfer of a message), anlatma fiilleri (tell), konuşma tarzı fiilleri (verbs of manner of speaking), iletişim araci fiilleri (verbs of instrument of communication), konuşma fiilleri (talk verbs), gevezelik fiilleri (chitchat verbs), söyleme fiilleri (say verbs), sizlanma fiilleri (complain verbs) ve tavsiye fiilleri (advise verbs) olmak üzere dokuza ayırmıştır. Bu çalışmada Levin'in tasnifine ek olarak memnuniyet fiilleri de ele alınmıştır. Risâletü' n-Nushiyye'de bu on alt fiil sınıfının kullanımları tespit edilmiş; bunların, Risâletü’n-Nushiyye'nin "Giriş Bölümü”, “1. Bölüm - Nefis (Açgözlülük ve Ruh (Gönül Zenginliği))", "2. Bölüm - Kendini Beğenme ve Alçak Gönüllülük”, "3. Bölüm - Öfke ve Sabır”, "4. Bölüm - Kıskançlık-Cimrilik ve Cömertlik", "5. Bölüm - Dedikodu-İftira ve Doğruluk" bölümlerindeki dağılımları gösterilmiştir.
\end{abstract}

Anahtar Kelimeler: Yunus Emre, Risâletü'n-Nushiyye, fiiller, iletişim fiilleri

Makale Türü: Araştırma

\begin{abstract}
Risâletü'n-Nushiyye was written by Yunus Emre in masnavi genre. Besides its literary value and the language material it contains, it is also important in terms of being one of the first advice books in the Anatolian field. In this sufistic and didactic work, it is seen that communication verbs, which are included as one of the basic classes in verb classifications, come to the fore in some parts. Verb classification attempts have been made by many researchers according to the morphological, syntactic and semantic properties of verbs. In this study, the use of communication verbs included in the classification studies according to the semantic features of verbs in Yunus Emre's Risâletü'n-Nushiyye will be discussed. The study will be based on Levin's work, which includes the communication verbs among 57 classes in which he separates the verbs according to their semantic features. In Levin's study, communication verbs is divided into nine groups as verbs of transfer of a message, tell, verbs of manner of speaking, verbs of instrument of communication, talk verbs, chitchat verbs, say verbs, complain verbs and advise verbs. In the study, verbs of praise were also added to these groups. The usage of these ten communication verb groups in Risâletü'n-Nushiyye will be determined. Their dispersion in 6 chapters of Risâletü'n-Nushiyye will be shown.
\end{abstract}

Keywords: Yunus Emre, Risâletü'n-Nushiyye, verbs, communication verbs

Paper Type: Research

\footnotetext{
${ }^{1}$ Eskişehir Osmangazi Üniversitesi, Fen-Edebiyat Fakültesi, Türk Dili ve Edebiyatı Bölümü, fdogru@ogu.edu.tr

Atıf için (to cite): Doğru, F. (2021). Risaletü'n-Nushiyye'de iletişim fiilleri. Afyon Kocatepe Üniversitesi Sosyal Bilimler Dergisi, 23(Yunus Emre ve Türkçe Özel Sayıs1), 138-154.
} 


\section{Giriş}

Fiil sınıflandırma denemeleri dil araştırmalarında en eski zamanlardan beri ilgi görmüştür. Fiiller, farklı özelliklerine göre çok sayıda sınıflandırmaya tabi tutulmuştur ${ }^{2}$. Özellikle fiillerin söz dizimsel ve anlam bilimsel özellikleri arasındaki ilişkiyi dikkate alarak yapılan sınıflandırma çalışmalarının yaygın olduğu görülmektedir (bk. Gruber, 1965; Pinker, 1989; Jackendoff, 1990; Dixon, 1991; Levin, 1993; Dang ve diğ., 1998; Korhonen ve Briscoe, 2004; Tamm, 2012, Dux, 2020 vd.). Bir dilin ya da daha özel olarak bir metnin söz varlı̆̆ıyla ilgili yapılan çalışmalarda söz konusu sınıflandırmalara sıklıkla başvurulduğu görülmektedir.

Fiil sınıflandırmalarında anlam bilimsel ölçütlerin dikkate alındığı, fiilleri kısmen daha ayrıntılı ya da yüzeysel öbeklere ayıran çalışmalar bulunmaktadır. Biber ve diğ. (1999, s. 360) birçok fiilin çok anlamlı bir yapıya sahip olmasından kaynaklanan zorlukların da varlığına dikkat çekerek fiilleri anlamsal alanlarına göre; hareket fiilleri (activity verbs), iletişim fiilleri (communication verbs), mental fiiller (mental verbs), nedensel fiiller (causative verbs), basit oluş fiilleri (verbs of simple occurrence), varoluş veya ilişki fiilleri (verbs of existence or relationship) ve görünüş fiilleri (aspectual verbs) olmak üzere yedi temel öbeğe ayırmıștır. Levin (1993) ise daha ayrıntılı bir sınıflandırma yaparak fiilleri 57 farklı öbeğe ayırır ve bunları da kendi içerisinde sahip olduğu anlamlara göre tasnif eder. Levin'in bu çalışması kendisinden sonra gelen çok sayıda araştırmacı tarafından kullanılmış ve araştırmalara dayanak oluşturmuştur (Dang ve diğ., 1998; Baker ve Ruppenhofer, 2002; Kipper ve diğ., 2007 vd.).

Bu çalışmada da Levin'in (1993) fiil sınıflandırması esas alınarak 57 fiil sınıfından biri olan "iletişim fiilleri" üzerinde durulacaktır. Çalışmanın amacı, Yunus Emre'nin Risâletü'nNushiyye adlı eserinde hangi iletişim fiillerini kullandığını belirlemek ve eserde yer alan iletişim fiillerinin eserin bölümlerine göre dağılımını ortaya koymaktır. Çalışmanın araştırma soruları şöyledir:

1. Yunus Emre, bir öğüt kitabı olması dolayısıyla iletişimin ön planda olduğu Risâletü'n-Nushiyye adlı eserinde hangi iletişim fiillerini kullanmıştır?

2. Eserde yer alan iletişim fiillerinin kendi içinde oluşturdukları alt türler nelerdir?

3. Eserin bölümlerine göre iletişim fiillerinin dağılımları nasıldır? Konuya göre kullanılan iletişim fiilleri değişkenlik göstermekte midir? Hangi bölümde hangi tür iletişim fiili daha fazla ya da daha az kullanılmıştır?

Çalışmada bu soruların yanıtı aranacak, ulaşılan sonuçlar tablolar yardımıyla gösterilmeye çalışılacaktır.

\section{1. İletişim Fiilleri}

İletişim fiilleri, iletişim etkinlikleri ve düşüncelerin aktarımını içeren bir alt fiil sınıfı olarak değerlendirilmektedir. Biber ve diğ. (1999, s. 362; 2002, s. 107) özellikle konuşma ve yazmayı tanımlayan edim fiillerinin bu sınıfa gireceğini belirtir ve karşılıklı konuşma, kurgu metinler, haber metinleri ve akademik metinlerde kullanılan en yaygın on iki İngilizce iletişim fiili olarak sor- (ask), ara- (call), iddia et- (claim), tanımla- (describe), teklif et- (offer), söyle(say), konuş- (speak), öner- (suggest), (karşıllkll) konuş- (talk), anlat- (tell), teşekkür et- (thank), ve $y a z$ - (write) fiillerini gösterir ${ }^{3}$.

\footnotetext{
${ }^{2}$ Hacıeminoğlu (2016: 16-17) fiilleri yapılarına göre, muhtevalarına göre, durumlarına göre, kullanılışlarına göre, fâil ile ilgilerine göre, nesne ile ilgilerine göre, mahiyetlerine göre olmak üzere 7 sınıfa ayırır. Barutçu Özönder (2011, s. 168-176) fiilleri, leksiksemantik açıdan, yapıları bakımından ve gramatik açıdan olmak üzere üç farklı biçimde ele alır. Biçim bilgisel, söz dizimsel ve anlam bilimsel ölçütlere göre yapılan bazı fiil sınıflandırma denemeleri için bk. Erdem (2016); Yıldız (2017); Doğan (2017); Doğan (2018).

${ }^{3}$ Önceki çalışmasında Biber ve diğ. (1999, s. 362), bu fiillerden başka duyur- (announce), tartış- (discuss), açıkla- (explain), bağır(shout) ve belirt- (state) fiillerini de yaygın örnekler arasında göstermiştir.
} 
Pinker (1989, s. 112) bu sinıf, iletiyi ve dinleyiciyi bildiren birer nesnenin ve araci olarak konuşmacının yer aldığı (Örn. Ali hikayeyi Ayşe'ye anlattı / yazdı / okudu / telsizle anlattı), yani X, Y'nin Z'yi bilmesine (algılamasına, kavramasına, farkında olmasına) neden olduğu dolayısıyla çift nesne yapısına imkan veren edimsel iletişim fiilleri olarak tanımlar ve "anlat- (tell), göster- (show), sor- (ask), ögret- (teach), soru sor- (pose), yaz- (write), (kafadan) uydur- (spin), oku- (read), alıntı yap- (quote), bahset- (cite)" örneklerini verir. Tematik İlişkiler Varsayımı'na (Thematic Relations Hypothesis) göre iletişim fiilleri, düşüncelerin iletişimini içeren bir sahiplik alt alanı içerir ve anlat-, sor-, yaz-vb. fiiller bir dinleyici üzerinde amaçlanan etkiye göre değişen farklı edimsel güce sahip iletileri belirtmelerinden dolayı farklılık gösterir. Söz gelimi bir dinleyicinin iletiyi bilmesi gerekiyorsa anlat-, öğrenmesi gerekiyorsa ögret-, cevaplaması gerekiyorsa sor-, okuması gerekiyorsa yaz-, görmesi gerekiyorsa göster- ya da duyup kavraması gerekiyorsa oku- fiilleri gereklidir (Pinker, 1989, s. 214). Goldberg (1995, s. 127) ise Pinker tarafından sıralanan fiillerin birçoğunun yanlış sınıflandırılmış olduğunu, iletilen mesaj fiilleri (verbs of communicated message) olarak adlandırdığı bu fiil sinıfının anlamsal olarak özünde iletişim eylemleri içerdiğinin anlaşılması gerektiğini belirtir. Ona göre Pinker'in vermiş̧ olduğu sor- (pose) ve (kafadan) uydur- (spin) örnekleri bu sınıfa girmez.

Ärnazarov (1982), sözleşik fiilleri (söyleyiş fiilleri) biçiminde ifade ettiği iletişim fiillerini önce genel anlamlı söyleyiş fiilleri ve farklı anlaml söyleyiş filleri olarak ikiye ayırmış; farklı anlamlı söyleyiş fïllerini de söyleme sürecinin içeriğini anlatan fiiller ve söyleme sürecinin tarzını anlatan fiiller olmak üzere ayrıca iki öbekte ele almıştır. Birinci öbek, yani söyleme sürecinin içeriğini anlatan fiiller ise duygu katkısı olmayan fiiller, olumlu duygu katkısı olan fiiller ve olumsuz duygu katkısı olan fiiller alt başlıkları altında üç öbeğe bölünmüşlerdir. (Aktaran, Erdem, 2007, s. 95-97; Soydan ve Saz, 2019, s. 860).

Bu çalışmada esas kabul edilen Levin'in (1993, s. 202-211) sınıflandırmasında iletişim fiilleri (verbs of communication) 9 ayrı alt başlık altında ele alınmıştır:

\section{Mesaj Aktarma Fiilleri (Verbs of Transfer of a Message)}

İletinin doğasına ve iletilme şekline göre farklılık gösteren bu fiiller Gropen ve diğ. (1989) tarafindan “('edimsel güç' gibi bir şey tarafindan ayırt edilen) iletilen mesaj türü fiilleri” [verbs of type of communicated message (differentiated by something like 'illocutionary force').] olarak adlandırılır (aktaran Levin, 1993, s. 203).

Örneğin: sor- (ask), bahset- (cite), göster- (demonstrate), dikte et- (dictate), açıkla(explain), izah et- (explicate), naklet- (narrate), oku- (read), göster- (show), ögret- (teach), anlat- (tell), yaz- (write) vd.

\section{Anlatma Fiilleri (Tell)}

Mesaj aktarma fiilleri arasında yer verilmiş olsa da anlat- fiili Levin tarafindan ayrıca ele alınmış ve iletişim fiilleri içerisindeki yerine vurgu yapılmıştır.

Örnek: (sadece) anlat- [tell (only)].

\section{Konuşma Tarzi Fiilleri (Verbs of Manner of Speaking)}

Bu sınıftaki fiiller sesin ifade ediliş biçimiyle birbirlerinden ayrılmaktadırlar. "Hayvan sesi fiilleri", "ses yayma fiilleri" vb. sinıflara da yer yer dâhil edilebilen bu sinıftaki fiiller, temelde sözsüz ifade fiilleri olduklarından "sözsüz ifade fiilleri" sınıfında da listelenmişlerdir. $\mathrm{Bu}$ fiillerin hem iletişimsel hem de iletişimsel olmayan kullanımlarının olabileceğini belirten Levin, söz dizimsel açıdan bu fiil sınıfındaki karmaşıklığa da ayrıca vurgu yapar (Levin, 1993, s. 205-206).

Örneğin: boşboğazlık et- (babble), bağır- (bark), kıkırda- (cackle), ağır konuş- (drawl), mırılda- (murmur), inle- (moan), çı̆̆lık at- (scream), şarkı söyle- (sing), yaygara kopar(squall), kekele- (stutter), fisilda- (whisper), haykır- (whoop) vd. 


\section{4. İletișim Aracı Fiilleri (Verbs of Instrument of Communication)}

$\mathrm{Bu}$ fiiller mutlaka bir iletişim aracı ile ilişkilendirilmişlerdir. Her zaman söz konusu iletişim araçlarının ses kullanması gerekmez (Levin, 1993, s. 207). Bu sınıfta yer alan fiillerin çoğunlukla tarihi dönemlerde kullanılan fiiller olmadıkları görülmektedir. Tarihi metinlerde ancak dönemin şartlarına uygun iletişim araçları ile birlikte kullanılan az sayıdaki fiil bu sınıfta değerlendirilebilir.

Örneğin: telgraf çek- (cable), e-posta at- (e-mail), faks çek- (fax), telefon et- (phone), radyodan yayınla-(radio), naklen yayın yap-(relay), sinyal ver- (signal), televizyondan yayınla(telecast), telgrafla gönder- (telegraph), telefon aç- (telephone), tel çek- (wire), telsizle haberleş(wireless) vd.

\section{Konuşma Fiilleri (Talk Verbs)}

Kapsamlı bir biçimde ele alındıklarında kendi aralarında da farklar görülebileceği hâlde konuş- (speak) ve (karşılıklı) konuş- (talk) fiillerini tek bir sınıfta değerlendiren Levin temel olarak anlamları "konuşmak" olduğundan dolayı böyle bir yola gittiğini belirtir ve bu fiillerin bir araç ya da tarz belirleme içermediğine vurgu yapar (Levin, 1993, s. 208).

Örneğin: konuş- (speak), (karşılıkll) konuş- (talk)

\section{Gevezelik Fiilleri (Chitchat Verbs)}

İki ya da daha fazla katılımcıdan oluşan sözlü etkileşimleri anlatan iletişim fiillerini içeren fiil sınıfıdır (Levin, 1993, s. 209).

Örneğin: tartış- (argue), sohbet et- (chat), çene çal- (chatter), gevezelik et- (chitchat), müzakere et- (confer), söyleş- (converse), çok konuş- (gab), dedikodu yap- (gossip), münakaşa et- (rap), boş konuş- (schmooze), çenesi düş- (yak).

\section{Söyleme Fiilleri (Say Verbs)}

Bu sinıfta yer alan fiiller, Gropen ve diğerleri tarafindan "önermesel tutum fiilleri ve önermesel iletişim fiilleri”" (verbs of communication of propositions and propositional attitudes) olarak tanımlanmakta olup üzerinde daha dikkatli ve kapsamlı bir çalışmanın yapılması gerekliliği vurgulanmıştır (aktaran Levin, 1993, s. 210).

Örneğin: duyur- (announce), telaffuz et- (articulate), ağzından kaçır- (blurt), iddia et(claim), itiraf et- (confess), sir ver- (confide), beyan et- (declare), bahset- (mention), söz et(note), teklif et- (propose), belirt- (remark), ezberden söyle- (repeat), rapor et- (report), söyle(say), ifade et- (state), tavsiye et- (suggest) vd.

\section{Sizlanma Fiilleri (Complain Verbs)}

Konuşmacının söylenenlere karşı tutumunu veya duygularını ifade eden fiillerin meydana getirdiği fiil sınıfidır (Levin, 1993, s. 211).

Örneğin: övün- (boast), böbürlen- (brag), şikayet et- (complain), sızlan- (crab), yakın(gripe), söylen- (grouch), dirdır et- (grouse), homurdan- (grumble), (sürekli) şikayet et(kvetch), itiraz et- (object).

\section{Tavsiye Fiilleri (Advise Verbs)}

Tavsiye fiilleri olarak adlandırılan fiiller tavsiye / öğüt veya uyarı vermekle ilgilidir (Levin, 1993, s. 212). Risâletü'n-Nushiyye'nin bir ögüt kitabı olması, insanlara tavsiyeler ve uyarılar vermek amacıyla yazılması iletişim fiilleri içerisinde bu sınıfta yer alan fiillere ayrı bir önem katmaktadır.

Örneğin: nasihat et- (admonish), ögütle- (advise), ikaz et- (alert), uyar-/tembihle(caution), nasihat ver-(counsel), talimat ver- (instruct), uyar- (warn). 
$\mathrm{Bu}$ çalışmada Levin'in bu sınıflandırmasına ayrıca "memnuniyet fiilleri” sınıfı da eklenmiş ve Levin'in yargı fiilleri (judgement verbs) sınıfında yer verdiği iletişim anlam alanına giren bazı fiiller bu kapsamda değerlendirilmiştir.

Fiiller anlamsal olarak sınıflandırılırken iletişim fiillerinin araştırmacılar tarafından farklı terimler kullanılarak adlandırıldıkları ve kimi zaman da ayrı bir öbek içerisine dâhil edildikleri de görülmektedir. Pinker (1989, s. 119) 13 alt sınıfa ayırdığı biçim bilgisel kısıtlamaya duyarlı, verileştirilebilir alt fiil sınıfları içerisinde iletişim/edimsel fiilleri (communication/illocutionary) ve iletissim aract fiillerini (instrument of communication) ayr1 ayrı ele almıştır. Goldberg (1995, s. 125-126) de sınırlayıcı fiil sınıfları başlığı altında Pinker'e atıfta bulunarak iletilen mesaj fiilleri (verbs of communicated message) ve iletişim aracı fiilleri (verbs of instrument of communication) sınıflarına yer vermiştir. Barutçu Özönder (2011, s. 168-169) fiillerin leksik-semantik açıdan, tematik olarak ele alınabileceğini gösterirken Tatar Türkçesinin dil bilgisi çalışmalarından hareketle Tatar Türkçesindeki fiillerin 11 alt sınıfa ayrıldığını belirtmiş ve iletişim fiillerini konuşma fiilleri başlığında göstermiştir. Ärnazarov (2004, s. 193-194) da Türkmen Türkçesi ve Türkiye Türkçesindeki ortak fiillerin oluşturduğu leksik-semantik fiilleri anlam bakımından 7 alt sınıfa ayırmış ve iletişim fiillerine bu sınıflar içerisinde nutuk fiilleri olarak yer verirken bazı iletişim fiillerini de sesleniş fiilleri içerisinde göstermiştir.

Batı alanyazınında iletişim fiilleri özelinde bu fiillerin söz dizimsel ve anlam bilimsel özellikleri arasındaki ilişkiden hareketle yapılan çalışmalar da dikkat çekmektedir (Urban ve Ruppenhofer, 2001; Boas, 2010; Viberg, 2016; Viberg, 2017a; Viberg, 2017b vd.). Ayrica iletişim fiillerinin ana dil konuşurlarıyla yabancı dil konuşurları arasındaki kullanım farkları derlem tabanlı olarak Partridge (2011) tarafından araştırılmıştır. Türkçe alanyazında da konuyla ilgili, Erdem (2007), Özavşar (2015), Bozdağ ve Badem (2017) ve Soydan ve Saz'ın (2019) çalışmaları öne çıkmaktadır. Erdem (2007) ile Soydan ve Saz (2019) Ärnazarov'un (1982) sınıflandırmasını esas alan araştırmalar yapmış; Özavşar (2015) iletişim fiilleri içerisinden yalnızca eyit-, di-, söyle- ve buyur- fiillerini ele almıştır. Bozdağ ve Badem (2017) ise iletişim fiillerinin yabancı dil öğrenimindeki durumunu derlem tabanlı olarak araştırmışlardır. Ayrıca Şirin'in (2020, s. 513-519) de konularına göre fiilleri sınıflandırdığı ve iletişim fiillerine etkileşim/iletişim sınıfında yer verdiği, bunları da kendi içinde oluş fiilleri ve kılış fiilleri olarak ikiye ayırdığ görülmektedir.

\section{Risâletü'n-Nushiyye}

Risâletü'n-Nushiyye, Yunus Emre'nin mesnevi nazım biçiminde yazmış olduğu tasavvufi ve öğretici bir içeriğe sahip nasihatname türünde bir eserdir. Eserin 556. beyitinden anlaşıldığ 1 üzere Risâletü'n-Nushiyye 1307 (H. 707) tarihinde kaleme alınmıştır (Boz, 2012, s. 4). Hemen hemen bütün Yunus Emre Divânı yazmalarında bulunan eserin bilinen ve en eski nüshaları arasında Fatih Nüshası (Süleymaniye Kütüphanesi, Fatih Bölümü, 3889), Karaman Nüshası, Yahya Efendi Nüshası (Süleymaniye Kütüphanesi, Hac1 Mahmud Efendi Bölümü, 3480), Nuruosmaniye Nüshası (4904) ve Bursa Nüshası (Bursa İl Halk Kütüphanesi, Eski Eserler Bölümü, 882) sayılabilir (Tatc1, 2008, s. 25-27). Eser, Giriş Bölümü ile birlikte asıl konunun işlendiği beş ana bölümden meydana gelmektedir.

\section{Giriş Bölümü}

1. beyit ila 13. beyit arasında bulunun beyitler ile XXIX satırlık mensur metinden oluşan Giriş Bölümü'nde 1-13. beyitler arasında Hz. Adem'in Allah tarafından yaratılış1 anlatılmakta, devam eden XXIX satırlık mensur metinde ise ak1l, iman, cennet, cehennem ve anasır-1 erbaa (âlemin yaratılışında esas teşkil eden dört unsur) konularından bahsedilmektedir (Boz, 2012, s. 6-11). 


\section{Bölüm - Nefis (Açgözlülük) ve Ruh (Gönül Zenginliği)}

14. beyit ila 82. beyit arasındaki beyitlerden oluşan bu bölümde insana havale edilen rahmani ve şeytani iki sultan olarak tasvir edilen ve insanın bunlardan hangisine bağlıysa onun hükmüne girdiği kabul edilen ruh ve nefis anlatılmakta; bunların arasındaki mücadeleden bahsedilerek insanın şeytani olan nefisten sakınması, uzaklaşması tavsiye edilmektedir (Tatcı, 2008, s. 10-12).

\section{Bölüm - Kendini Beğenme ve Alçak Gönüllülük}

83. beyit ila 180. beyit arasında yer alan beyitlerden oluşan bu bölümde kibir (kendini beğenme) ile tevazu (alçak gönüllülük) kavramları arasında bir karşılaştırma vardır. Kibir, kötü ve tehlikeli bir huy olarak gösterilirken kibir için dăg sembolü kullanılmış; tevazu ise övülmüş ve yer sembolü kullanılarak ifade edilmiștir. İnsanın ancak kendini beğenmeyi bırakarak tevazuya ulaşabileceğinin anlatıldığ bu bölüm, mücadele sonunda kaçan kendini beğenmenin alçak gönüllülük tarafından mağlup edilmesiyle son bulur (Tatc1, 2008, s. 12-14; Boz, 2012, s. 14-16).

\section{Bölüm - Öfke ve Sabır}

181. beyit ila 302. beyit arasındaki beyitlerden oluşan bu bölümde buşu sözcügüyle ifade edilen öfkenin zararları ele alınmaktadır. İnsanın öfkeden kurtulması tavsiye edilmekte ve bunun için de sabrın gerekliliği vurgulanmaktadır. Ak1l, öfkeden kurtulmak için sabır ve doğruluğun bulunması gerektiğini söyler ve bunun sonucunda ortaya çıkan sabır, öfkeyi yok eder (Tatc1, 2008, s. 16; Boz, 2012, s. 17).

\section{Bölüm - Kıskançlık-Cimrilik ve Cömertlik}

303. beyit ila 438. beyit arasındaki beyitlerden oluşan bu bölümde hased sözcügüüle ifade edilen kıskançlık ve buhl sözcüğüyle ifade edilen cimriliğin yol açtıkları zararlar ele alınmmakta ve bu kötü hasletlerden Allah'ın yardımıyla cömertlik sayesinde kurtulunabileceği vurgulanmaktadır (Tatc1, 2008, s. 18; Boz, 2012, s. 22).

\section{Bölüm - Dedikodu-İftira ve Doğruluk}

439. beyit ila 562. beyit arasında yer alan beyitlerden oluşan bu bölümde şair, gaybet (dedikodu) ve bühtan (yalan) konuları üzerinde durur. Dedikodu ve iftiranın son derece kötü huylar olduğu, insan ve toplum yapısını bozduğu, insanları kendisinden, Allah'tan, ve gerçeklerden uzaklaştırdığı, insanlar tarafından sıradanlaştılmalarının kötü olacağı belirtilmektedir. Her bölümün sonunda olduğu gibi bu bölümün sonunda da akıl ortaya çıkar. Aklın, doğruluğa dedikodu evini yıktırması sonucu insan nefsin ve şeytanın kötülüklerinden kurtulup huzura erebilir (Tatc1, 2008, s. 19-22; Boz, 2012, s. 23-28).

\section{Yöntem}

İletişim fiilleri yazılı ve sözlü metinlerin çok büyük bir bölümünü oluşturan bir fiil sınıfıdır. Biber ve diğ. (1999, s. 365) bir milyon sözcükte en az elli kez geçen yaygın fiiller içerisinden yedi anlamsal alan belirlemiş ve bunların içerisinde iletişim fiilleri 36 sözcüksel birim ve \%13 kullanımla en çok kullanılan fiiller arasında yer almıştır. Bu yaygın kullanıma rağmen az sayıda iletişim fiilinin kullanım bakımından diğerlerine oranla çok daha fazla yaygınlık kazandığı görülmektedir. Söz gelimi Viberg (2017a, s. 37) 1 milyon sözcükten oluşan İsveç Stockholm Umeå Derlemi'nde 400 iletişim fiilinin yer aldığını ancak bunların içinde en sık kullanılan 10 tanesinin toplam iletişim fiili kullanımının \%50'sine yakınını oluşturduğunu belirtir. Az sayıda iletişim fiilinin çok yaygın kullanılmasının yanında bazı iletişism fiillerinin de metin türüne göre yaygınlık kazandığı, metin türünün kullanılan iletişim fiilini ve bunların sayısını etkilediği görülmektedir. Biber ve diğ. (1999, s. 366) derlem tabanlı olarak karşılıklı konuşma, kurgu metinler, haber metinleri ve akademik metinlerde kullanılan iletişim fiillerinin oranlarını ve türlere göre yaygınlıklarını göstermişlerdir. Buna göre iletişim fiilleri söz edilen 
türler içerisinde en çok kurgu metinlerde, en az akademik metinlerde görülmektedir. Bu bilgilerden hareketle bu çalışmada, kurgu metin niteliğindeki Risâletü'n-Nushiyye'de kullanılan iletişim fiillerini tespit etmek ve bunların konulara göre dağılımlarını ortaya koymak hedeflenmektedir.

Çalışmanın ilk basamağında Yunus Emre'nin Risâletü'n-Nushiyye adlı eserinin söz varlığı taranmıştır. Tarama sonucunda fiil sınıflandırmalarında "iletişim fiili" olarak değerlendirilen fiiller çıkarılmış ve bunlar da Levin'in (1993) sınıflandırmasına göre kendi içinde öbeklere ayrılmıştır. Fiillerin anlamlarının belirlenmesinde Boz (2012) tarafından hazırlanan Risâletü'n-Nushiyye'nin Bağlamsal Sözlük ve Dizin bölümünden yararlanılmıştır. Giriş Bölümü ve farklı konuları anlatan beş ana bölümden oluşan Risâletü'n-Nushiyye'nin her bir bölümü, iletişim fiillerinin kullanımı bakımından ayrıca değerlendirilmiş; bölümler kendi içinde karşılaş̧ırılarak iletişim fiillerinin bir eser içerisinde konuya göre kullanımında farklar bulunup bulunmadığı ortaya konmaya çalışılmıştır. Elde edilen bulgular tablolar yardımıyla gösterilmiş ve karşıllaştırılmıştır. Sınıflandırma yapılırken çok anlamlılığa da dikkat edilmiş; tablolarda çok anlamlı fiillerin anlam numaraları üst simge biçimindeki rakamlarla gösterilmiştir.

Çalışmada yalnızca fiil görevindeki sözcükler değerlendirme kapsamına alınmış, fiilden türemiş isimler ve fiil dışındaki sözcük türleri kapsam dışında tutulmuştur. Yardımcı fiillerle birlikte kullanılan sözcükler ise kapsama dahil edilmiştir. Birleşik fiil yapısındaki iletişim fiilleri (gaybet söyle-, haber vir- vb.) ayrı bir iletişim fiili olarak sayılmıştır.

Çalışma, Levin'in (1993) sınıflandırmasına göre yapılsa da Levin'in verdiği örneklerde yer almayan ancak eserde geçen iletişim fiilleri de fiilin anlamsal özelliğine göre çalışmaya dâhil edilmiş, gerektiğinde Levin'in vermiş olduğu alt türlere ilaveten yeni bir alt tür eklenmiş ve Levin'in çalışmasına bu anlamda katkı sunulmuştur.

\section{Bulgular ve Tartışma}

Risâletü'n-Nushiyye adlı eser üzerinde yapılan inceleme sonucunda eserde tek sözcükten oluşan 31, birleşik fiil yapısında 27 olmak üzere toplam 58 farklı iletişim fiili tespit edilmiş ve bu fiillerin metinde toplamda $155 \mathrm{kez}$ kullanıldığı görülmüştür. Tablo 1'de Risâletü'n-Nushiyye'de kullanılan iletişim fiillerinin yapılarına göre sayıları gösterilmektedir.

Tablo 1. Risâletü'n-Nushiyye'de yapısına göre iletişim fiillerinin sayıları

\begin{tabular}{lcc}
\hline Fiil yapısı & İletişim Fiili Sayısı & Toplam Kullanım Sayısı \\
\hline Tek sözcüklü fiiller & 31 & 126 \\
Birleşik fiiller & 27 & 30 \\
Toplam & 58 & 155 \\
\hline
\end{tabular}

Toplam 5866 sözcükten meydana gelen Risâletü'n-Nushiyye'de 58 farklı iletişim fiili toplamda $155 \mathrm{kez}$ kullanılmıştır. Eserin \%2.64'ünü iletişim fiilleri oluşturmaktadır. Birleşik sözcüklerle birlikte eserde yer alan 1631 farklı sözcükbirim içinde 58 farklı iletişim fiili ise eserin söz varlığının \%3.56'sını meydana getirir. Eserde 530 farklı fiil 1433 kez kullanılmıştır. $\mathrm{Bu} 530$ farklı fiilden \%10.94'ünün iletişim fiili, 1433 fiil kullanımından \%10.82'sinin ise iletişim fiili kullanımı olduğu görülmüştür. Bu oranların Biber ve diğg. (1999, s. 365) tespit ettiği \%13 iletişim fiili kullanım oranına yakın olduğu söylenebilir.

İletişim fiillerinin eserin konularına göre dağılımına bakıldığında 5. Bölüm'ün (Dedikodu-İftira ve Doğruluk) öne çıktığı görülmektedir. Toplam 1265 sözcüğün kullanıldığı 5. Bölüm'de 47 iletişim fiili kullanılmış ve bu bölümün \%3.72'sini iletişim fiilleri oluşturmuştur. Diğer bölümlerle karşılaştırıldığında (bk. Tablo 2) 5. Bölüm'de çok daha fazla iletişim fiilinin kullanıldığı tespit edilmiştir. Bu kullanım oranının ortaya çıkmasında 5. Bölüm'ün konusunun "dedikodu" olması etkili olmuştur denilebilir. Giriş Bölümü’nde bulunan toplam 335 sözcükten 11'i, 1. Bölüm'deki 667 sözcükten 15'i, 2. Bölüm'deki 972 sözcükten 20'si, 3. Bölüm'deki 1242 sözcükten 30’u, 4. Bölüm'deki 1385 sözcükten 32'si, 5. Bölüm'deki 1265 sözcükten 47'si 
iletişim fiilidir. Tablo 2'de Risâletü'n-Nushiyye'de kullanılan iletişim fiillerinin konulara göre dağılımı gösterilmektedir.

Tablo 2. Risâletü’n-Nushiyye'de kullanılan iletişim fiillerinin konulara göre dağılımı

\begin{tabular}{|c|c|c|c|}
\hline Bölüm & $\begin{array}{c}\text { Toplam } \\
\text { Sözcük } \\
\text { Sayısı }\end{array}$ & $\begin{array}{c}\text { Toplam } \\
\text { İletişim } \\
\text { Fiili } \\
\text { Kullanım } \\
\text { Sayısı }\end{array}$ & $\begin{array}{c}\text { İletişim } \\
\text { Fiillerinin } \\
\text { Toplam } \\
\text { Sözcük } \\
\text { Sayısına } \\
\text { Oranı }\end{array}$ \\
\hline Giriş Bölümü & 335 & 11 & $\% 3.28$ \\
\hline 1. Bölüm - Nefis (Açgözlülük) ve Ruh (Gönül Zenginliği) & 667 & 15 & $\% 2.25$ \\
\hline 2. Bölüm - Kendini Beğenme ve Alçak Gönüllülük & 972 & 20 & $\% 2.06$ \\
\hline 3. Bölüm - Öfke ve Sabır & 1242 & 30 & $\% 2.42$ \\
\hline 4. Bölüm - Kıskançlık-Cimrilik ve Cömertlik & 1385 & 32 & $\% 2.31$ \\
\hline 5. Bölüm - Dedikodu-İftira ve Doğruluk & 1265 & 47 & $\% 3.72$ \\
\hline Toplam & 5866 & 155 & $\% 2.64$ \\
\hline
\end{tabular}

Eserde tespit edilen iletişim fiilleri kendi içinde Levin'in (1993) sınıflandırmasına göre anlamları göz önünde bulundurularak alt sınıflara ayrılmıştır. Her bir alt sınıf özelinde, bu sınıflarda yer alan iletişim fiillerinin eserin bölümlerine göre dağılımları ayrı ayrı gösterilmiştir.

\subsection{Mesaj Aktarma Fiilleri (Verbs of Transfer of a Message)}

Risâletü'n-Nushiyye'de 15 farklı mesaj aktarma fiilinin 25 kez kullanıldığ görülmektedir. Tablo 3'te bu fiillerin hangileri olduğu ve bölümlere göre dağılımları gösterilmektedir. Bütün bölümlerde mesaj aktarma fiillerinin yer aldığı görülmekte olup en fazla mesaj aktarma fiiline 5. Bölüm'de (Dedikodu-İftira ve Doğruluk) rastlanmaktadır.

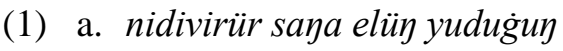

seni unutdurur mı okudugiun (224)

b. niçe devrān kim anda rı̂hlı urdù

okuyup Ǿaşr u àyet yolda turduך (246)

(1a)'da ok,u- fiili "kitap vb.den bilgi öğrenmek" anlamında, (1b)'de ise aynı fiil "seslendirmek" anlamında kullanılmıştır. Örneklerde görüldüğü gibi çok anlamlı fiillerin hangi anlamı eserin ilgili bölümünde iletişim fiili olarak kullanılmışsa, tabloda o anlam numarası ${ }^{4}$ üst simge olarak gösterilmiştir.

Tablo 3. Risâletü'n-Nushiyye'de bölümlere göre mesaj aktarma fiilleri

\begin{tabular}{|c|c|c|c|}
\hline Bölüm & İletişim Fiili ve Beyit No & $\begin{array}{l}\text { İletişim } \\
\text { Fiili Sayıs1 }\end{array}$ & $\begin{array}{c}\text { Toplam } \\
\text { Kullanım } \\
\text { Sayısı }\end{array}$ \\
\hline Giriş Bölümü & ad eyle- (3), ileT- (III, III, IV), bildür- (ÒVIII) & 3 & 5 \\
\hline $\begin{array}{l}\text { 1. Bölüm - Nefis (Açgözlülük) ve } \\
\text { Ruh (Gönül Zenginliği) }\end{array}$ & ћaber vir- (18), śor- (42), śuǿāl it- (49), şerh iT- & 4 & 4 \\
\hline $\begin{array}{l}\text { 2. Bölüm - Kendini Beğenme ve } \\
\text { Alçak Gönüllülük }\end{array}$ & $\begin{array}{c}\text { degir- }(86), d i-{ }^{3}(89), \text { haber ver- }(83),{\text { ile } T-{ }^{1}}^{1} \\
(171)\end{array}$ & 4 & 4 \\
\hline 3. Bölüm - Öfke ve Sabır & 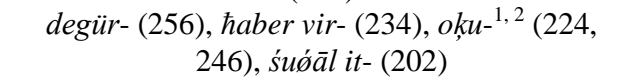 & 4 & 5 \\
\hline $\begin{array}{l}\text { 4. Bölüm - Kıskançlık-Cimrilik ve } \\
\text { Cömertlik }\end{array}$ & bildür- $(326)$ & 1 & 1 \\
\hline $\begin{array}{l}\text { 5. Bölüm - Dedikodu-İftira ve } \\
\text { Doğruluk }\end{array}$ & 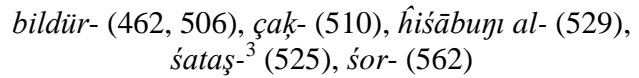 & 5 & 6 \\
\hline Toplam & & $15^{5}$ & 25 \\
\hline
\end{tabular}

\footnotetext{
4 Anlam numaraları Boz’un (2012) hazırladığı Risâletü’n-Nushiyye'nin Bağlamsal Sözlük ve Dizin bölümündeki sırasıyla verilmiştir.

${ }^{5}$ Sütundaki sayıların toplamı her ne kadar 15 olsa da her bölümde tekrar eden iletişim fiilleri (söz gelimi ilet- fiili hem Giriş Bölümü’nde hem 2. Bölüm'de; bildür- fiili hem Giriş Bölümü, hem 4. Bölüm hem de 5. Bölüm'de yer almıştır) bu sayıdan
} 


\subsection{Anlatma Fiilleri (Tell)}

Risâletü'n-Nushiyye'de 2 farklı anlatma fiilinin 3 kez kullanıldığı görülmektedir. Tablo 4'te bu fiillerin hangileri olduğu ve bölümlere göre dağılımları gösterilmektedir. Giriş Bölümü, 4. Bölüm ve 5. Bölüm’de anlatma fiili sınıfına girecek bir fiile rastlanmamıştır.

(2) gel imdi digle sözi şerh ideyin

birin birin anı saya diyeyin (14)

Eserde anlat- biçimindeki fiil yer almamaktadır. Ancak (2)'de görüldüğü gibi di- ve göster- fiilleri "anlatmak" anlamıyla kullanıldığında bu fiiller anlatma fiilleri içerisine dâhil edilmiştir.

Tablo 4. Risâletü'n-Nushiyye'de bölümlere göre anlatma fiilleri

\begin{tabular}{|c|c|c|c|}
\hline Bölüm & İletişim Fiili ve Beyit No & $\begin{array}{l}\text { İletişim } \\
\text { Fiili Sayıs1 }\end{array}$ & $\begin{array}{c}\text { Toplam } \\
\text { Kullanım } \\
\text { Sayısı } \\
\end{array}$ \\
\hline Giriș Bölümü & & - & - \\
\hline $\begin{array}{l}\text { 1. Bölüm - Nefis (Açgözlülük } \\
\text { ve Ruh (Gönül Zenginliği) }\end{array}$ & $d i^{2}(14)$ & 1 & 1 \\
\hline $\begin{array}{l}\text { 2. Bölüm - Kendini Beğenme } \\
\text { ve Alçak Gönüllülük }\end{array}$ & göster- ${ }^{1}(83)$ & 1 & 1 \\
\hline 3. Bölüm - Öfke ve Sabır & $d i-^{2}(269)$ & 1 & 1 \\
\hline $\begin{array}{l}\text { 4. Bölüm - Kiskançlık- } \\
\text { Cimrilik ve Cömertlik }\end{array}$ & & - & - \\
\hline $\begin{array}{l}\text { 5. Bölüm - Dedikodu-İftira ve } \\
\text { Doğruluk }\end{array}$ & & - & - \\
\hline Toplam & & 2 & 3 \\
\hline
\end{tabular}

\subsection{Konuşma Tarzı Fiilleri (Verbs of Manner of Speaking)}

Risâletü'n-Nushiyye'de 5 farklı konuşma tarzı fiilinin 7 kez kullanıldığı görülmektedir. Tablo 5'te bu fiillerin hangileri olduğu ve bölümlere göre dağılımları gösterilmektedir. Giriş Bölümü, 2. Bölüm ve 5. Bölüm'de konuşma tarzı fiilleri sınıfına girecek bir fiile rastlanmamıştır.

(3) ider feryād yire k, vereyin

ki boynumdan vebāli indüreyin (352)

Eserde en fazla konuşma tarzı fiili 4. Bölüm'de (Kıskançlık-Cimrilik ve Cömertlik) görülmektedir. $\mathrm{Bu}$ bölümün konusunun, konuşma tarzı fiillerin kullanımına daha fazla yer imkân tanıdığı söylenebilir.

çıkarıldığında toplam mesaj aktarma fiili sayısı elde edilecektir. Bu nedenle sütunlarda yer alan sayıların toplamıyla toplam satırında yer alan sayılar her zaman örtüşmeyebilir. 
Tablo 5. Risâletü’n-Nushiyye'de bölümlere göre konuşma tarzı fiilleri

\begin{tabular}{|c|c|c|c|}
\hline Bölüm & İletişim Fiili ve Beyit No & $\begin{array}{l}\text { İletişim } \\
\text { Fiili Sayıs1 }\end{array}$ & $\begin{array}{c}\text { Toplam } \\
\text { Kullanım } \\
\text { Sayıs1 }\end{array}$ \\
\hline Giriş Bölümü & & - & - \\
\hline 1. Bölüm - Nefis & dili dutul-(39) & 1 & 1 \\
\hline (Açgözlülük ve Ruh (Gönül & & & \\
\hline \multicolumn{4}{|l|}{ Zenginliği) } \\
\hline 2. Bölüm - Kendini & & - & - \\
\hline Beğenme ve Alçak & & & \\
\hline \multicolumn{4}{|l|}{ Gönüllülük } \\
\hline 3. Bölüm - Öfke ve Sabır & cevāb vir- (205), dirākna k,op- (201) & 2 & 2 \\
\hline $\begin{array}{l}\text { 4. Bölüm - Kiskançlık- } \\
\text { Cimrilik ve Cömertlik }\end{array}$ & ağzı din- (376), feryād iT- $(352,359,391)$ & 2 & 4 \\
\hline $\begin{array}{l}\text { 5. Bölüm - Dedikodu-İftira } \\
\text { ve Doğruluk }\end{array}$ & & - & - \\
\hline Toplam & & 5 & 7 \\
\hline
\end{tabular}

\section{4. İletişim Aracı Fiilleri (Verbs of Instrument of Communication)}

Risâletü'n-Nushiyye'de iletişim aracı fiilleri sınıfına girebilecek bir fiile rastlanmamıştır. Levin' in (1993, s. 206) örnek olarak verdiği telgraf çek- (cable), e-posta at- (email), faks çek- (fax), telefon et- (phone), radyodan yayınla- (radio), naklen yayın yap-(relay), sinyal ver- (signal), televizyondan yayınla- (telecast), telgrafla gönder- (telegraph), telefon aç(telephone), tel çek- (wire), telsizle haberleş- (wireless) vd. teknolojiyle ilgili iletişim araci fiilleri göz önüne alındığında 1307 yılında kaleme alınan bir eserde bunların yer almaması normaldir. Ancak dönemin iletişim teknolojisine uygun az sayıda iletişim aracı fiilinin (mektup yaz-, ulak gönder- vb.) eserde yer alması beklenebilir ki Yunus Emre'nin eserinde bunlara da yer vermediği görülmüştür.

\subsection{Konuşma Fiilleri (Talk Verbs)}

Risâletü'n-Nushiyye'de konuşma fiilleri sınıfına girebilecek bir fiile rastlanmamıştır. Levin'in (1993, s. 207) örnek olarak verdiği konuş- (speak, talk) biçiminde bir fiil eserde hiç yer almadığı gibi bu anlama yakın olarak değerlendirilebilecek di-, eyit-, söyle- vb. fiiller anlamsal olarak daha yakın olarak değerlendirildikleri diğer sınıflar içerisinde ele alınmıştır.

\subsection{Gevezelik Fiilleri (Chitchat Verbs)}

Risâletü'n-Nushiyye'de 5 farklı gevezelik fiilinin 5 kez kullanıldığı görülmektedir. Tablo 6'da bu fiillerin hangileri olduğu ve bölümlere göre dağılımları gösterilmektedir. Giriş Bölümü, 1. Bölüm, 2. Bölüm, 3. Bölüm ve 4. Bölüm'de gevezelik fiilleri sınıfına girecek bir fiile rastlanmamıştır.

$$
\begin{aligned}
& \text { kişinüy hayżıdur ag்zında ġaybet } \\
& \text { ki ġaybet söyleyen bulmaya rahmet (449) }
\end{aligned}
$$

Eserde tespit edilen gevezelik fiillerinin tamamı 5. Bölüm'de (Dedikodu-İftira ve Doğruluk) görülmektedir. Bu bölümün konusunun dedikodu olmasının, böyle bir sonucun ortaya çıkmasında etkili olduğu söylenebilir. Açıkça görülmektedir ki eserin konusu ile eserde kullanılan iletişim fiili arasında doğrudan bir ilişki vardır. 
Tablo 6. Risâletü’n-Nushiyye'de bölümlere göre gevezelik fiilleri

\begin{tabular}{|c|c|c|c|}
\hline Bölüm & İletişim Fiili ve Beyit No & $\begin{array}{l}\text { İletişim } \\
\text { Fiili Sayıs1 }\end{array}$ & $\begin{array}{c}\text { Toplam } \\
\text { Kullanım } \\
\text { Sayıs1 }\end{array}$ \\
\hline \multicolumn{4}{|l|}{ Giriş Bölümü } \\
\hline \multirow{2}{*}{\multicolumn{4}{|c|}{$\begin{array}{l}\text { 1. Bölüm }- \\
\text { (Açgözlülük ve Ruh (Gönül }\end{array}$}} \\
\hline & & & \\
\hline \multicolumn{4}{|l|}{ Zenginliği) } \\
\hline 2. Bölüm - Kendini & & & \\
\hline Beğenme ve & & & \\
\hline \multicolumn{4}{|l|}{ Gönüllülük } \\
\hline \multicolumn{4}{|l|}{ 3. Bölüm - Öfke ve Sabır } \\
\hline \multirow{2}{*}{\multicolumn{4}{|c|}{ 4. Bölüm - Kıskançlık- }} \\
\hline & & & \\
\hline $\begin{array}{l}\text { 5. Bölüm - Dedikodu-İftira } \\
\text { ve Doğruluk }\end{array}$ & $\begin{array}{c}{\text { ay }-{ }^{2}}^{(528)} \text {, gaybet söyle- }(449), \text { gaybete uy- } \\
(531), \text { glybet evin ylk- }(537), \text { söyle- }{ }^{3}(515)\end{array}$ & 5 & 5 \\
\hline Toplam & & 5 & 5 \\
\hline
\end{tabular}

\subsection{Söyleme Fiilleri (Say Verbs)}

Risâletü'n-Nushiyye'de 16 farklı söyleme fiilinin 87 kez kullanıldığı görülmektedir. Tablo 7'de bu fiillerin hangileri olduğu ve bölümlere göre dağılımları gösterilmektedir.

(5) ne söz söylerise havśalası dar ne dinse tarlıgiıdan biy daћı var (334)

Eserde tespit edilen söyleme fiillerinin sözcükbirim olarak sayılarının nispeten az ancak kullanım sayılarının buna oranla çok daha fazla olduğu dikkat çekmektedir. Sözcükbirim olarak en fazla söyleme fiili ( 8 farklı fiil) 4. Bölüm'de (Kıskançlık-Cimrilik ve Cömertlik) görülmekteyken en fazla kulanım $29 \mathrm{kez}$ ile 5. Bölüm'de (Dedikodu-İftira ve Doğruluk) görülmektedir. $\mathrm{Bu}$ bölümlerin konularının, bölümlerde kullanılan iletişim fiillerinin fazla olmasıyla yakından bir ilişkisi vardır. 
Tablo 7. Risâletü'n-Nushiyye'de bölümlere göre söyleme fiilleri

\begin{tabular}{|c|c|c|c|}
\hline Bölüm & İletişim Fiili ve Beyit No & $\begin{array}{l}\text { İletişim } \\
\text { Fiili Sayı1 }\end{array}$ & $\begin{array}{c}\text { Toplam } \\
\text { Kullanım } \\
\text { Sayısı }\end{array}$ \\
\hline Giriş Bölümü & $d i^{-1}(2,3,8)$ & 1 & 3 \\
\hline $\begin{array}{l}\text { 1. Bölüm - Nefis } \\
\text { (Açgözlülük ve Ruh (Gönül } \\
\text { Zenginliği) }\end{array}$ & $\begin{array}{c}\text { de- }(41,41), \text { di- }^{1}(50,55), \text { eyüt- }(42), \text { gel- }^{2} \\
(14), \text { söyle- }{ }^{2}(81)\end{array}$ & 5 & 7 \\
\hline $\begin{array}{lcr}2 . \quad \text { Bölüm } & - & \text { Kendini } \\
\text { Beğenme } & \text { ve } & \text { Alçak } \\
\text { Gönüllülük } & & \end{array}$ & $\begin{array}{c}\text { beşāaret eyle- }(173) \text { de- }(86,149) \text { di- }^{1}(83,87, \\
91,139), \text { gel- }^{2}(98,176), \text { göyül bāzāarrn it- } \\
\text { (122), selām ver- }(147)\end{array}$ & 6 & 11 \\
\hline 3. Bölüm - Öfke ve Sabır & $\begin{array}{c}\text { de- }(279,189,203), \text { di- }^{1} \quad(255,282,285, \\
241,212,241), \text { gel- }^{2}(181,233), \text { iT- }^{2}(181), \\
\text { Ø̈̈źür göster- }(203), \text { söyle- }^{2}(258), \text { söylen- } \\
(259)\end{array}$ & 7 & 15 \\
\hline $\begin{array}{l}\text { 4. Bölüm - Kiskançlık- } \\
\text { Cimrilik ve Cömertlik }\end{array}$ & $\begin{array}{l}\text { de- }(344,429), \text { den- }(396), \text { di- }^{1}(323,422, \\
324,344,388,369,350,303,310,392,373), \\
\text { din- }(334), \text { ey }(i)-_{-}^{2}(435,354,394), \text { gel- }^{2} \\
(417), \text { söyle- }^{2}(376,334), \text { şart eyle- }(360)\end{array}$ & 8 & 22 \\
\hline $\begin{array}{l}\text { 5. Bölüm - Dedikodu-İftira } \\
\text { ve Doğruluk }\end{array}$ & $\begin{array}{c}\text { de- }(548,508), \text { di- }^{1} \quad(495,534,475,497, \\
558,559,485,546,507,482,463,469,474, \\
520,485,553,533), \text { ey(i)T- }^{2}(439), \text { gel }^{2} \\
(439,461,462), \text { göster- }^{3}(455,481), \text { söyle- }^{2} \\
(517,518,517), \text { söylen- }(516)\end{array}$ & 7 & 29 \\
\hline Toplam & & 16 & 87 \\
\hline
\end{tabular}

\subsection{Sizlanma Fiilleri (Complain Verbs)}

Risâletü'n-Nushiyye'de 3 farklı sızlanma fiilinin 4 kez kullanıldığı görülmektedir. Tablo 8'de bu fiillerin neler olduğu ve bölümlere göre dağılımları gösterilmektedir. Giriş Bölümü, 1. Bölüm, 2. Bölüm ve 4. Bölüm'de sızlanma fiilleri sınıfına girecek bir fiile rastlanmamıştır.

(6) özüni izlemez ayrugì śınar

ki togru kim varısa anı k̦inar (208)

Yunus Emre'nin eserinde sızlanma anlamı içeren fiillere çok fazla yer vermediği göze çarpmaktadır. Özellikle (6)' da görüldüğü gibi ķına- fiilinin eserde yer bulduğu görülür. 
Tablo 8. Risâletü'n-Nushiyye'de bölümlere göre sızlanma fiilleri

\begin{tabular}{|c|c|c|c|}
\hline Bölüm & İletişim Fiili ve Beyit No & $\begin{array}{l}\text { İletişim } \\
\text { Fiili Sayıs1 }\end{array}$ & $\begin{array}{c}\text { Toplam } \\
\text { Kullanım } \\
\text { Sayıs }\end{array}$ \\
\hline \multirow{2}{*}{\multicolumn{4}{|c|}{$\begin{array}{l}\text { Giriş Bölümü } \\
\text { 1. Bölüm } \quad-\quad \text { Nefis }\end{array}$}} \\
\hline & & & \\
\hline \multicolumn{4}{|l|}{ (Açgözlülük ve Ruh (Gönül } \\
\hline \multicolumn{4}{|l|}{ Zenginliği) } \\
\hline 2. Bölüm & & & \\
\hline \multicolumn{4}{|l|}{ Beğenme ve Alçak } \\
\hline \multicolumn{4}{|l|}{ Gönüllülük } \\
\hline 3. Bölüm - Öfke ve Sabır & ķına- (208), karşu tur- (206) & 2 & 2 \\
\hline 4. Bölüm - Kiskançlık- & & & \\
\hline & & & \\
\hline $\begin{array}{l}\text { 5. Bölüm - Dedikodu-İftira } \\
\text { ve Doğruluk }\end{array}$ & ķına- (521), ǩınan- (513) & 2 & 2 \\
\hline \multicolumn{2}{|l|}{ Toplam } & 3 & 4 \\
\hline
\end{tabular}

\subsection{Memnuniyet Fiilleri}

Levin'in (1993, s. 195) "birinin bir şeye tepki olarak sahip olabileceği bir yarg1 veya görüşle ilgili fiiller” olarak nitelendirdiği ve yargı fiilleri (judgement verbs) başlığında verdiği fiillerin bazılarının iletişim fiili özelliği taşıdığı düşünüldüğünden Levin'in iletişim fiilleri başlığ 1 altında yer vermediği bu alt sınıf tarafimızca oluşturulmuştur. Türkçedeki öv-, teşekkür et-, şükür et-, hamd et-, alkışla-, methet- vb. fiiller iletişim anlam alanında kullanıldıklarında bu sınıfa girerler. Risâletü'n-Nushiyye'de 5 farklı memnuniyet fiilinin 8 kez kullanıldığ görülmektedir. Tablo 9'da bu fiillerin hangileri olduğu ve bölümlere göre dağılımları gösterilmektedir.

(7) sükür kıldı hak, ol devlet issi irürdi devlete Ǿaķll bilüsi (174)

Memnuniyet fiillerinin, sılanma fiillerinin görülmediği bölümlerde kullanılması; sızlanma fiillerinin görüldüğü 3. Bölüm'de (Öfke ve Sabır) görülmemesi, 5. Bölüm'de (Dedikodu-İftira ve Doğruluk) ise bir kez görülmüş olması dikkat çekicidir. Memnuniyet fiillerinin (7)'deki örnekte görüldügü gibi daha çok yaratıcı ile olan iletişimde kullanılması yine eserin ve bölümlerin konusuyla yakından ilgilidir.

Tablo 9. Risâletü'n-Nushiyye'de bölümlere göre memnuniyet fiilleri

\begin{tabular}{|c|c|c|c|}
\hline Bölüm & İletişim Fiili ve Beyit No & $\begin{array}{l}\text { İletişim Fiili } \\
\text { Sayısı }\end{array}$ & $\begin{array}{c}\text { Toplam } \\
\text { Kullanım } \\
\text { Sayıs1 } \\
\end{array}$ \\
\hline Giriş Bölümü & hamd it- (8) & 1 & 1 \\
\hline $\begin{array}{l}\text { 1. Bölüm } \quad-\quad \text { Nefis } \\
\text { (Açgözlülük ve Ruh } \\
\text { Zenginliği) }\end{array}$ & şükür eyle- (40) & 1 & 1 \\
\hline $\begin{array}{l}\text { 2. Bölüm - Kendini Beğenme } \\
\text { ve Alçak Gönüllülük }\end{array}$ & $\ddot{o g}-(165,165)$, şükür ķıl- $(174)$ & 2 & 3 \\
\hline $\begin{array}{l}\text { 3. Bölüm - Öfke ve Sabır } \\
\text { 4. Bölüm - Kıskançlık- } \\
\text { Cimrilik ve Cömertlik }\end{array}$ & alkuş iT- (315), ög- (315) & 2 & 2 \\
\hline $\begin{array}{l}\text { 5. Bölüm - Dedikodu-İftira } \\
\text { ve Doğruluk }\end{array}$ & $\ddot{o g}-(472)$ & 1 & 1 \\
\hline
\end{tabular}




\subsection{Tavsiye Fiilleri (Advise Verbs)}

Bir öğüt kitabı niteliğinde olan Risâletü'n-Nushiyye'de tavsiye fiillerinin yer alması da kaçınılmazdır. Eserde 10 farklı tavsiye fiilinin 16 kez kullanıldığı görülmektedir. Tablo 10'da bu fiillerin hangileri olduğu ve bölümlere göre dağılımları gösterilmektedir.

(8) a. çü gine geldi Ǿaķl ögütler anı

bize gelenlerü̈ ķurtuldı cānı (54)

Eserde tespit edilen tavsiye fiillerinin 3. Bölüm (Öfke ve Sabır), 4. Bölüm (KıskançlıkCimrilik ve Cömertlik) ve 5. Bölüm'de (Dedikodu-İftira ve Doğruluk) daha fazla kullanılarak bir kümelenme oluşturdukları dikkat çekmektedir. Sözcükbirim olarak en fazla tavsiye fiili (5 farklı fiil) ve en fazla kulanım (5 kez) 3. Bölüm'de (Öfke ve Sabır) görülmektedir. Bu bölümdeki kümelenme, bölüm konusu ile ilişkilendirilebilir.

Tablo 10. Risâletü'n-Nushiyye'de bölümlere göre tavsiye fiilleri

\begin{tabular}{|c|c|c|c|}
\hline Bölüm & İletişim Fiili ve Beyit No & $\begin{array}{l}\text { İletişim Fiili } \\
\text { Sayısı }\end{array}$ & $\begin{array}{c}\text { Toplam } \\
\text { Kullanım } \\
\text { Sayısı } \\
\end{array}$ \\
\hline Giriş Bölümü & fermān ol- (6), söyle- ${ }^{1}(1)$ & 2 & 2 \\
\hline $\begin{array}{l}\text { 1. Bölüm - Nefis (Açgözlülük } \\
\text { ve Ruh (Gönül Zenginliği) }\end{array}$ & ögütle- (54) & 1 & 1 \\
\hline $\begin{array}{l}\text { 2. Bölüm - Kendini Beğenme } \\
\text { ve Alçak Gönüllülük }\end{array}$ & danış- (175) & 1 & 1 \\
\hline 3. Bölüm - Öfke ve Sabır & $\begin{array}{c}\text { buyur- }^{2} \text { (258), ey }(i) T-{ }^{1}(261) \text { śına- (208), söyle- }{ }^{1} \\
\text { (254), tanışık iT- (233) }\end{array}$ & 5 & 5 \\
\hline $\begin{array}{l}\text { 4. Bölüm - Kıskançlık- } \\
\text { Cimrilik ve Cömertlik }\end{array}$ & buyur- $^{2}(405,410)$, sekit- $(436)$ & 2 & 3 \\
\hline $\begin{array}{l}\text { 5. Bölüm - Dedikodu-İftira ve } \\
\text { Doğruluk }\end{array}$ & buyur- $^{2}(508,535,458)$, dokl $-(482)$ & 2 & 4 \\
\hline Toplam & & 10 & 16 \\
\hline
\end{tabular}

\section{Sonuç ve Öneriler}

Yunus Emre'nin yazdığı Risâletü'n-Nushiyye adlı eserde kullanılan iletişim fiilleri ile ilgili yapılan inceleme sonucunda eserde iletişim fiil türlerinden en fazla söyleme fiillerinin, daha sonra sırasıly mesaj aktarma fiilleri, tavsiye fiilleri, memnuniyet fiilleri, konuşma tarzı fiilleri, gevezelik fiilleri, sızlanma fiilleri ve anlatma fiillerinin kullanıldığı; iletişim aracı fiilleri ile konuşma fiillerinin eserde yer almadığı tespit edilmiştir. Çalışmada, Levin'in (1993) iletişim fiillerini ayırdığı dokuz alt türe çalışmada memnuniyet fiilleri de eklenmiştir. Risâletü'nNushiyye'de kullanılan iletişim fiillerinin türlerine göre dağılımı Tablo 11'de gösterilmiştir.

Tablo 11. Risâletü'n-Nushiyye'de kullanılan iletișim fiillerinin türlerine göre dağılımı

\begin{tabular}{lcc}
\hline İletişim Fiilinin Türü & İletişim Fiili Sayıs1 & Toplam Kullanım Sayısı \\
\hline 1. Mesaj Aktarma Fiilleri & 15 & 25 \\
2. Anlatma Fiilleri & 2 & 3 \\
3. Konuşma Tarzı Fiilleri & 5 & 7 \\
4. İletişim Aracı Fiilleri & - & - \\
5. Konuşma Fiilleri & - & - \\
6. Gevezelik Fiilleri & 5 & 5 \\
7. Söyleme Fiilleri & 16 & 87 \\
8. Sizlanma Fiilleri & 3 & 4 \\
9. Memnuniyet Fiilleri & 5 & 8 \\
10. Tavsiye Fiilleri & 10 & 16 \\
Toplam & $58^{6}$ & 155 \\
\hline
\end{tabular}

\footnotetext{
${ }^{6}$ Sütunda yer alan sayıların toplamı 61 yapsa da bu sayı fiillerdeki çok anlamlılıktan dolayı ortaya çıkmıştır. Çok anlamlılık göz ardı
} edildiğinde toplam sözcükbirim sayısı 58 olarak hesaplanmıştır. 
Eserde en çok kullanılan iletişim fiili di- fiilidir (47 kez). Bunu sırasıyla $11 \mathrm{kez}$ kullanılan de- fiili ve $10 \mathrm{kez}$ kullanılan söyle-fiili izlemektedir.

Eserin bölümlerine göre bakıldığında bölümlerde işlenen konunun kullanılan iletişim fiillerinde etkili olduğu görülmüştür. Konuya göre kullanılan iletişim fiillerinin türüne bağl1 olarak yer yer değişkenlik göstermekte olduğu belirlenmiştir. Gevezelik fiilleri yalnızca 5 . Bölüm'de (Dedikodu-İftira ve Doğruluk) kullanılmıştır. 4. Bölüm'de (Kıskançlık-Cimrilik ve Cömertlik) diğer bölümlerde nispeten yoğun olarak kullanılan mesaj aktarma fiilleri çok daha az kullanılmaktayken diğer bölümlerde nispeten daha az kullanılan veya hiç kullanılmayan konuşma tarzı fiilleri ve söyleme fiilleri daha fazla kullanılmıştır. Eserdeki iletişim fiili türlerinin eserin bölümlerine göre dağılımları Tablo 12'de gösterilmiştir.

Tablo 12. Risâletü’n-Nushiyye'de kullanılan iletişim fiil türlerinin konulara göre dağılımı

\begin{tabular}{|c|c|c|c|c|c|c|}
\hline $\begin{array}{l}\text { İletişim Fiilinin } \\
\text { Türü }\end{array}$ & $\begin{array}{c}\text { Giriş̧ } \\
\text { Bölümü }\end{array}$ & $\begin{array}{l}\text { 1. Bölüm- } \\
\text { Nefis } \\
\text { (Açgözlülük } \\
\text { ve Ruh } \\
\text { (Gönül } \\
\text { Zenginliği) }\end{array}$ & $\begin{array}{l}\text { 2. Bölüm- } \\
\text { Kendini } \\
\text { Beğenme ve } \\
\text { Alçak } \\
\text { Gönüllülük }\end{array}$ & $\begin{array}{c}3 . \\
\text { Bölüm- } \\
\text { Öfke ve } \\
\text { Sabır }\end{array}$ & $\begin{array}{l}\text { 4. Bölüm- } \\
\text { Kıskançlık- } \\
\text { Cimrilik ve } \\
\text { Cömertlik }\end{array}$ & $\begin{array}{l}\text { 5. Bölüm- } \\
\text { Dedikodu- } \\
\text { İftira ve } \\
\text { Doğruluk }\end{array}$ \\
\hline $\begin{array}{l}\text { Mesaj Aktarma } \\
\text { Fiilleri }\end{array}$ & $3(5)^{7}$ & $4(4)$ & $4(4)$ & $4(5)$ & $1(1)$ & $5(6)$ \\
\hline Anlatma Fiilleri & - & $1(1)$ & $1(1)$ & $1(1)$ & - & - \\
\hline $\begin{array}{l}\text { Konuşma Tarzı } \\
\text { Fiilleri }\end{array}$ & - & $1(1)$ & - & $2(2)$ & $2(4)$ & - \\
\hline $\begin{array}{l}\text { İletişim Aracı } \\
\text { Fiilleri }\end{array}$ & - & - & - & - & - & - \\
\hline Konuşma Fiilleri & - & - & - & - & - & - \\
\hline Gevezelik Fiilleri & - & - & - & - & - & $5(5)$ \\
\hline Söyleme Fiilleri & $1(3)$ & $5(7)$ & $6(11)$ & $7(15)$ & $8(22)$ & $7(29)$ \\
\hline Sizlanma Fiilleri & - & - & - & $2(2)$ & - & $2(2)$ \\
\hline $\begin{array}{l}\text { Memnuniyet } \\
\text { Fiilleri }\end{array}$ & $1(1)$ & $1(1)$ & $2(3)$ & - & $2(2)$ & $1(1)$ \\
\hline Tavsiye Fiilleri & $2(2)$ & $1(1)$ & $1(1)$ & $5(5)$ & $2(3)$ & $2(4)$ \\
\hline
\end{tabular}

Daha hacimli bir çalışmada Risâletü'n-Nushiyye'de yer alan bütün fiiller sınıflandırılarak eser içerisinde yer alan iletişim fiillerinin diğer fiil sınıflarına oranı da tespit edilebilir. Ayrıca farklı metin türlerinden seçilecek metinlerdeki iletişim fiillerinin diğer fiil sınıflarına göre kullanım oranlarının edebi eserlerde, özellikle de nasihatnamelerdeki kullanım oranlarıyla bir karşılaştırması yapılabilir. Böylelikle bu çalışmada eserin bölümlerine göre farklılıklar gösterdiği ortaya konan iletişim fiillerinin metin türlerine göre kullanımında da bir fark bulunup bulunmadığ 1 tespit edilebilecektir.

\section{Kaynakça}

Ärnazarov, S. N. (1982). Türkmen dilinde sözleyiş işlikleri. Aşgabat: Türkmenistan SSR Ilımlar Akademiyas1.

Ärnazarov, S. N. (2004). Türkmen ve Türkiye Türkçesinin ortak fiillerinin anlam bakımından genel bir mukayesesi. V. Uluslararası Türk Dili Kurultayı Bildirileri I içinde, (ss. 193-220). Ankara: Türk Dil Kurumu Yayınları.

Baker, C. F., ve Ruppenhofer, J. (2002). FrameNet's frames vs. Levin's verb classes. J. Larson ve M. Paster (Ed.) Annual Meeting of the Berkeley Linguistics Society içinde, (C. 28, No. 1, ss. 27-38) Berkeley: University of California.

\footnotetext{
${ }^{7}$ Yay ayraç dışındaki sayı metinde geçen her bir farklı iletişim fiilini, yay ayraç içindeki sayı ise bunların metinde toplamda kaç kez kullanıldığını gösterir. Bu örnekteki sayılar, 3 farklı iletişim fiilinin metinde 5 kez geçtiğini ifade eder.
} 
Barutçu Özönder, S. (2011). Türk dilinde fiil ve fiil çekimi. Türk Gramerinin Sorunları içinde (ss. 168-176). Ankara: Türk Dil Kurumu Yayınları.

Biber, D.; Conrad, S. ve Leech, G. (2002). Longman student grammar of spoken and written English. Harlow: Longman.

Biber, D.; Johansson, S.; Leech, G.; Conrad, S. ve Finegan, E. (1999). Longman grammar of spoken and written English. Londra: Longman.

Boas, H. C. (2010). The syntax-lexicon continuum in Construction Grammar: A case study of English communication verbs. Belgian Journal of Linguistics, 24, s. 54-82. https://doi.org/10.1075/bj1.24.03boa

Boz, E. (Hazırlayan) (2012). Yunus Emre Risâletü’n-Nushiyye, Öğüt Kitabl, Ankara: Gazi Kitabevi.

Bozdağ, F. ve Badem, N. (2017). A comparison of communication verbs used by Turkish EFL learners and English native speakers: a corpus based study. Gaziantep University Journal of Social Sciences, 16 (3), s. 879-891. DOI: 10.21547/jss.315063

Dang, H. T., Kipper, K., Palmer, M., ve Rosenzweig, J. (1998). Investigating regular sense extensions based on intersective Levin classes. 36th Annual Meeting of the Association for Computational Linguistics and 17th International Conference on Computational Linguistics, Volume 1, Montreal, Kanada, s. 293-299.

Dixon, R. (1991). A new approach to English grammar, on semantic principles. Oxford: Clarendon Press.

Doğan, N. (2017). Türkçe fiillerin anlam bilimsel sınıfları. I. Uluslararası Dil ve Edebiyatta Modernleşme ve Gelenek Sempozyumu Bildiriler Kitabl, s. 223-252, Karabük: Karabük Üniversitesi Yayınları.

Doğan, N. (2018). Söz dizimsel açıdan Türkçe fiil sınıfları. Uluslararası Türkçe Edebiyat Kültür Eğitim Dergisi Say1: 7/4 s. 2204-2225.

Dux, R. (2020). Frame-constructional verb classes: change and theft verbs in English and German. Amsterdam / Philadelphia: John Benjamins Publishing Company.

Erdem, M. (2007). Oğuz grubu Türk lehçelerinde iletişim fiilleri. Modern Türklük Araşstırmaları Dergisi, 4(2), s. 94-103.

Erdem, M. (2016). Türkçede fiiller ve sinıflandırma sorunları. Turkish Studies International Periodical for the Languages, Literature and History of Turkish or Turkic, Volume 11/20, s. 185-200.

Goldberg, A. E. (1995). Constructions: A construction grammar approach to argument structure. Şikago ve Londra: University of Chicago Press.

Gruber, J. S. (1965). Studies in lexical relations. (Yayımlanmamış doktora tezi). Massachusetts Institute of Technology, Amsterdam: Nonh-Holland.

Hacıeminoğlu, N. (2016). Türk dilinde yapı bakımından fiiller: en eski Türkçe metinlerden zamanımıza kadar -yazı dilinde-. İstanbul: Bilge Kültür Sanat Yayınları.

Jackendoff, R. S. (1990). Semantic structures, Londra: Massachusetts Institute of Technology Press.

Kipper, K., Korhonen, A., Ryant, N., ve Palmer, M. (2007). A large-scale classification of English verbs. Language Resources and Evaluation, 42(1), s. 21-40. 
Korhonen, A., ve Briscoe, T. (2004). Extended lexical-semantic classification of English verbs. Proceedings of the Computational Lexical Semantics Workshop at HLT-NAACL 2004, Boston, MA, s. 38-45.

Levin, B. (1993). English verb classes and alternations: a preliminary investigation. Chicago and London: University of Chicago press.

Özavşar, R. (2015). Marzubannâme Tercümesi'nde eyit-, di-, söyle- ve buyur- fiilleri. Akademik Sosyal Araştırmalar Dergisi, Y11: 3, Sayı: 19, s. 128-139.

Partridge, M. (2011). A comparison of lexical specificity in the communication verbs of L1 English and TE student writing. 1. Southern African Linguistics and Applied Language Studies, 29(2), s. 135-147.

Pinker, S. (1989). Learnability and cognition: The acquisition of argument structure. Cambridge: Massachusetts Institute of Technology Press.

Soydan, S. ve Saz, M. (2019). Lisânü't Tayr'da iletişim fiilleri. Turkish Studies - Language and Literature, 14(2), s. 855-878. doi: 10.29228/TurkishStudies.22503

Şirin, H. (2020). Eski Türk yazıtları söz varlı̆̆ı incelemesi (2. bask1). Ankara: Türk Dil Kurumu Yayınlar1.

Tamm, A. (2012). Scalar verb classes: scalarity, thematic roles, and arguments in the Estonian aspectual lexicon. Firenze: Firenze University Press.

Tatc1, M. (2008). Risâletü'n-Nushiyye, Tenkitli Metin. İstanbul: H Yayınları.

Urban, M. ve Ruppenhofer, J. (2001). Shouting and screaming: Manner and noise verbs in communication. Literary and Linguistic Computing, 16, s. 77-97. https://doi.org/10.1093/llc/16.1.77

Viberg, Å. (2016). Asking and answering: A contrastive study of English and Swedish basic communication verbs. Linguistics Beyond and Within (LingBaW), 2(2), s. 180-212.

Viberg, Å. (2017a). Saying, talking and telling - basic verbal communication verbs in Swedish and English. Egan, T., ve Dirdal, H. (Ed.) Cross-linguistic correspondences: From lexis to genre içinde, (ss. 37-74), Amsterdam: John Benjamins Publishing Company.

Viberg, Å. (2017b). Finding a model for contrastive lexical semantics: A look at verbal communication verbs. Linguistics Beyond and Within (LingBaW), 3(3), s. 195-215.

Yıldız, H. (2017). Türk dilinde fiillerin semantik sinıflandırılması problemi. Littera Turca Journal of Turkish Language and Literature, 3(1), s. 337-362.

\section{ETİK ve BİLIMSEL İLKELER SORUMLULUK BEYANI}

$\mathrm{Bu}$ çalışmanın tüm hazırlanma süreçlerinde etik kurallara ve bilimsel atıf gösterme ilkelerine riayet edildiğini yazar(lar) beyan eder. Aksi bir durumun tespiti halinde Afyon Kocatepe Üniversitesi Sosyal Bilimler Dergisi'nin hiçbir sorumluluğu olmayıp, tüm sorumluluk makale yazarlarına aittir. 